УДК 39 (477.87) (437.6) (438)

DOI 10.24919/2519-058x.5.116977

Володимир НАКОНЕЧНИЙ, orcid.org/0000-0002-0386-2162 кандидат історичних наук, доцент кафедри міжнародних відносин Київського національного університету культури і мистецттв (Україна, Київ) nakonechniy.ua@gmail.com

\title{
РУСИНСЬКА СПІЛЬНОТА МІЖВОСННОЇ ПОЛЬЩІ У ВИСВІТЛЕННІ «НАШОГО ЛЕМКА»
}

\begin{abstract}
У статті досліджено становище русинів у міжвоєнній Польщі за матеріалами газети «Наш лемко». 3'ясовано найбільш складні проблеми, щуо поставали перед лемками в 1920-1930-х рр. Підсумовано, щзо газета стала визначним явищем русинської періодики, котре в складних умовах міжвоєнного часу зуміло об'єднати лемків ідеями збереження власної культурної ідентичності та плекання загальноначіональної єдності.
\end{abstract}

Ключові слова: міжнародні відносини, «Наш лемко», Юліан Тарнович, лемкознавство, польська держава.

Jim. 59.

Volodymyr NAKONECHNYI, Ph D (History), Associate Professor of International Relationships Department of Kyiv National University of Culture and Arts

(Ukraine, Kyiv) nakonechniy.ua@gmail.com

\section{RUTHENIAN COMMUNITY OF INTERWAR POLAND IN TERMS OF «OUR LEMKO»}

In the article an emphasis is made on the fact that the Second Rzecz Pospolita inplemented an unbearable pressure on the Lemkos, Ukraine's most western ethnic group. In official documentation they were recognized as the Poles who needed a "help» in search for their national identity. Lemkos'dispersion (due to the specific conditions of living), as well as their greatly diversed ethnic environment, facilitated the assimilation of the original Ukrainian territories by the Polish invaders and complicated the preservation of the historic memory by the Lemko people. These processes found a rather complete reflection on the pages of the biweekly «Nash Lemko». This newspaper, which was the only Ukrainian edition during the interwar twenty years, not only addressed the Lemko readers, but had been created by the Lemkos themselves. Along with the implementation of an important task of internal mobilization of the Ruthenian environment as such, "Nash Lemko» also presented the Ruthenians alias Rusyny to the outside world as politically mature sub-ethnos whose representatives, in spite of the occupying power's pressure, express their national self-perception in terms and concepts of Ukrainian being. Thus, an important tradition of the Lemkos'self-identifications as the Ukrainians was established at a time when our people was in the process of overcoming complicated internal and external challenges.

The investigation proves, that along with the implementation of important educational and informational functions, the newspaper also became a significant factor in the social maturing of the Lemkos movement, transforming it into a prominent phenomenon of the political life of the Polish state. This made it impossible to use the Lemkos ethnic factor by different occupants in their attempt to split the Ukrainian national front on the eve and during the Second World War. Therefore, it is no coincidence that the traditions of «Nash Lemko» proved to be extremely popular in the second half of the twentieth century.

Key words: international relationships, "Nash Lemko» biweekly, Julian Tarnovich, Lemko studies, Polish state.

Ref. 59. 
Владимир НАКОНЕЧНЫЙ, кандидат исторических наук, доцент кафедры международных отношений Киевского национального университета культуры и искусств (Украина, Киев) nakonechniy.ua@gmail.com

\title{
РУСИНСКОЕ СООБЩЕСТВО МЕЖВОЕННОЙ ПОЛЬШИ В ОСВЕТЛЕНИИ «НАШОГО ЛЕМКА»
}

\begin{abstract}
В статье исследовано положение русинов в межвоенной Польше по материалам газеть «Наш лемко». Выяснено наиболее сложные проблемы, которые возникали перед лемками в 1920-1930-х га. Сделан вывод, что газета стала выдаюшимся явлением русинской периодики, сумевшим в сложных условиях межвоенного времени объединить лемков идеями сохранения собственной культурной идентичности и общенационального единства.
\end{abstract}

Ключевые слова: международные отночения, «Наш лемко», Юлиан Тарнович, лемковедение, польское государство.

Лит. 59.

Постановка проблеми. Загальновідомо, що Друга Річ Посполита була вкрай неприхильно налаштована до своїх національних меншин, передовсім до українців. Тут зазвичай згадуються найбільш промовисті гвалтовні спроби денаціоналізації корінного населення Східної Галичини, включно з намаганнями адміністративно нав'язати вживання етноніму «русини» замість «українці», як і топоніму «Східна Малопольща» замість «Східна Галичина». Втім, практично не згадується, що значно більшого тиску польської державної машини зазнала найзахідніша етнографічна група українців - лемки. Йдеться про те, що якщо поляки все-таки визнавали національну окремішність своїх «русинів» і мусили зважати на їхню політичну зрілістю та кількісну домінацію в краї, то зовсім іншою була ситуація з лемківським населенням. В офіційній документації вони були визнані за поляків, котрим треба «допомогти» віднайти національну ідентичність. Розпорошеність лемків (внаслідок гірської специфіки умов проживання), як і здебільшого іноетнічне оточення, полегшували справу польським загарбникам одвічних українських теренів, як і ускладнювали збереження самими лемками своєї історичної пам'яті. Ці та інші проблеми знайшли доволі повне відбиття на сторінках двотижневика «Наш лемко».

Аналіз останніх досліджень. Часопис «Наш Лемко» протягом тривалого часу є одним із найбільш популярних періодичних видань у середовищі дослідників русинського субетносу. Особливо багато на сьогодні написано про працю головного редактора часопису - визначного діяча лемківського руху Юліана Тарновича [8; 45]. Про вагомість для лемкознавців опублікованих на шпальтах газети матеріалів свідчить той промовистий факт, що за останні роки з'явилися дві тематичні збірки дописів 3 «Нашого лемка» [32]. Водночас і сьогодні відсутній самостійний аналіз цього видання як інформаційного джерела для висвітлення становища лемків у міжвоєнний час. Цим і зумовлена актуальність нашого дослідження.

Мета статті полягає у спробі комплексного аналізу матеріалів «Нашого лемка» як інформаційного джерела про становище русинського субетносу в складі Другої Речі Посполитої.

Виклад основного матеріалу. Поява «Нашого лемка» була викликана сумними реаліями національної політики, котру проводила у міжвоєнний час польська окупаційна адміністрація. Йдеться про те, що після незаконної анексії західноукраїнських земель після закінчення Першої світової війни, польські чиновники взяли курс на гвалтовну полонізацію своїх східних територій. Користаючи з невиразності національної самоідентифікації значної частини українського населення Лемківщини, державні органи спрямували значні зусилля на те, щоб переконати лемків обрати або польську, або, принаймні, москвофільську етнічну ідентичність. Для цього були виділені значні кошти, на які видавалися лемківські часописи польською та російською мовами, створювалися відповідні навчальні заклади нижчої ланки, провадилася культурна політика, спрямована на розмивання почуття єдності лемків зі своїми братами на Великій Україні. Тож на порозі фактичного національного розчинення у «польському морі», свідомими діячами лемківського руху цілком виправдано було вирішено видавати газету, покликану формувати у лемківському 
середовищі розуміння, з одного боку, унікальності власної духовної та матеріальної культури, 3 іншого - історичної та ментальної єдності лемків з українцями інших регіонів. Цим періодичним виданням і став «Наш лемко», котрий видавався у Львові неповних шість років з 1 січня 1934 до 1 вересня 1939 p.

Саме ідея національної єдності лемків та українців з інших теренів стала структуруючою при формуванні редакційного портфелю «Нашого лемка»; у різних варіаціях вона пронизує більшість газетних дописів. Водночас з метою приваблення масового читача, редактори газети звернули увагу й на інші виклики часу, відповіді на які мав би давати «Наш лемко». Серед них найбільш гострими були злиденність, малоземелля, неписьменність, вилюднення етнічних земель лемків внаслідок вимушеної масової еміграції, громадська апатія та пов'язана 3 нею епідемія шкідливих звичок (передусім, алкоголізму) тощо.

Про готовність дати відповіді на згадані виклики часу, видавці «Нашого лемка» писали вже у першому зверненні до читача: «3 нинішнім числом зачинає «Народня Слава» видавати «Нашого Лемка». Радіймо з того дуже, бо маємо свою газету. Вона є дійсно наша власна. Промовляє до нас навіть нашим говором. Виходити буде «Наш Лемко» два рази в місяць, а будемо в тій газеті писати письменницькою мовою і нашим лемківським говором. Письменницькою мовою тому, щоби дати читачам взірець поправної мови, такої, якою говорять коло Києва, якою писали наші поети, як: Тарас Шевченко, Іван Франко і нині пишуть всі письменники, та яку ми всі повинні знати. Читаючи статті написані письменницькою мовою, Лемки пізнають і пересвідчаться, що лемківський говір є і духом і складнею (порядком і укладом слів) рідною дитиною загальної нашої рідної письменницької мови, а не якоїсь іншої, чужої. А не-Лемки (бо і такі будуть читати нашу газету) пізнають один зі старих і рідних наших говорів, яким $є$ лемківський говір. Виходить «Наш Лемко» в світ в тій надії, що зайде в кожне лемківське село, під кожду лемківську стріху, до читальні й до кооперативи, на забаву й на весілля, всюде, де лиш б’'єься рідне слово. Врешті, що буде милою розрадою кождої лемківської родини на еміграції. Тому отворім «Нашому Лемкови» гостинно хату, як наймилішому гостеви та приймім його щиро в родину, хай разом з нами поділяє нашу долю й недолю. Най буде нашим сердечним опікуном, щирим оборонцем і розумним дорадником. Ставаймо в ряди передплатників «Нашого Лемка», щоби наша громада була, якнайбільша!» [41].

Заохочуючи лемків передплачувати нове видання, редакція газети обіцяла своєму читачеві всебічну консультативну підтримку у найрізноманітніших проблемах духовного життя та матеріального побуту. При цьому цікавою $є$ ієрархія тих життєвих викликів, що на них обіцяв у діяльний спосіб реагувати новий часопис. На сторінках першого числа автентичною лемківською говіркою 3 цього приводу йшлося: ««Наш Лемко» буде приносити найважнійши відомости зо світа и про життя і розквіт цілого нашого народу, а зокрема, про нас, Лемків. Буде показувати нашим людям, што гнески без науки і школи тяжко дати сой го світу раду і што ми для свого и нашого дітий добра, повинни тіж гуртуватися в наших читальнях и кооперативах. «Наш Лемко» буде давати господарски поради, як поліпшити нашу газдівку в горах, штоби легше нам було жити. Ретельним передплатникам буде давати задармо ветеринарни, правничи и лікарськи поради, як наприклад: як вилічити груду коньови, як вистаратися о спадок по родині в Гамериці, або што робити, аби в грудях не пекло і инши. Буде друкувати цікави оповіданя з лемківського життя, описи красних лемківських звичаїв, новинки, пригоди і жарти. Буде писати про життя лемківської еміграції в Гамериці и інших краях. Буде радити, як визискати богацтва, што сут на нашій земли. Буде тіж друкувати дописи з лемківських сіл, але лем таки, што г них ся никого поневинні не чернит и таки, штоби другим була $з$ них наука. «Наш Лемко» для точних передплатників тіжик придумат дуже цикавих і пожиточних несподіванок. Презто висилайте зараз передплату на «Нашого Лемка»!» [40].

Реалізації щойно згаданих завдань та цілей сприяла добре продумана структурна архітектоніка «Нашого Лемка». При цьому відзначимо, що рубрикація газети стала предметом багатолітнього творчого пошуку для іiі видавців, що у тісному спілкуванні зі своїм читачем осмислювали оптимальну логіку розташування матеріалу. Тож у підсумку усталилися постійні рубрики, котрі фокусувалися на: поточних новинах (світового, державного, загальноукраїнського та суто лемківського масштабу); інформації про духовну та матеріальну культуру русинів; історичних 
і культурологічних екскурсах; широкому спектрі реалізації практичних потреб (фінансових, сільськогосподарських, правничих та ін.). Для важливого зворотного зв'язку зі своїм читачем, редактори видання провадили рубрики «Листування» та «Трибуна наших Читачів». Самостійне смислове навантаження несло художнє оформлення часопису: на його шпальтах завжди експонувалися важливі для кожного лемка візуальні образи (краєвиди рідної землі, світлини церков та культурних інституцій, врешті, іконографія заслужених діячів лемківського руху та ін.). 3 газетою співпрацював відомий графік Едвард Козак. Слід відзначити також добре продуманий колпортаж нового видання - в короткому часі воно стало поширюватися в країнах Свропи і на американському континенті. Про затребуваність і популярність газети свідчить хоча б той факт, що при незмінній ціні, від року до року збільшувався обсяг кожного числа: перший річник налічував 196 с., другий - 210 с., третій - 230 с., четвертий та п'ятий - по 300 с.

Як і годилося провідній русинській медійній трибуні, у «Нашому лемкові» особлива увага редактора була звернена на поінформування читачів про біжучі події. Ця інформація була сфокусована у рубриках «Що нового в світі» та «Що чувати в світі». Очікувано, що передовсім йшлося про вагомі для пересічної людини новини державного рівня. Відзначимо, що протягом всіх років свого існування часопис був доволі опозиційно налаштований до польської держави, гостро засуджуючи політику вульгарної денаціоналізації русинського субетносу. Наслідки цієї гострокритичної постави і сьогодні впадають у вічі читачеві «Нашого лемка» - нерідко його шпальти рясніють білими полосами видалених цензурою матеріалів. Згадаємо також, що цілковито сконфіскованим виявилося вже перше число «Нашого лемка». Звернемо увагу колег-лемкознавців на той унікальний факт, що Наукова бібліотека ім. М. Драгоманова у Львові має комплект газети, котрий належав цензурному комітету, тобто в ньому єдиному можемо бачити всі заплановані тексти до їхньої конфіскації!

Не меншу небезпеку видавці газети вбачали у русифікації лемків, адже у їхньому середовищі традиційно популярними були культурні старорусинські традиції. Автори газети переконували своїх читачів, що слов'янофільство галицьких будителів першої половини XIX ст. немає нічого спільного з агресивною поставою модерного москвофільства, адепти якого через зухвалу пропаганду намагаються зруйнувати єдність лемківського паростка з українським етнічним стовбуром $[10 ; 35]$.

Доволі багато на сторінках «Нашого лемка» йшлося про життя українських побратимів в інших регіонах - як у Західній Україні, так і за Збручем. Інформуючи русинів про різноманітні події загальнонаціонального життя, дописувачі газети і тут постійно наголошували на єдності українців усіх етнічних регіонів, невтомно з номера в номер утверджуючи ідею соборності. Попри певну складність комунікації з радянськими землями, у кожному числі газети вміщувалися інформаційні нариси про життя зазбручанських земляків. Разом зі схваленням культурних та економічних здобутків радянських українців, редакція «Нашого лемка» не закривала очей на промовисті факти скочування керівництва радянської держави до тоталітаризму та тиранії, що несло загрозу для національних меншостей імперії з боку «старшого брата». Демонструючи цинізм радянської пропаганди, дописувачі «Нашого лемка» називали більшовиків «вовками в овечій шкурі» [21; 22].

Утім, найбільш розлога інформаційна рубрика - «Новинки» - стосувалася, зрозуміло, справ самих лемків. У цьому плані «Наш лемко» постає справжньою енциклопедією русинського життя в другій половині 1930-х рр., в якій знайшли відображення практично всі аспекти їхнього буття: культурні, політичні, економічні, релігійні тощо. При цьому привертає увагу особлива насиченість релігійної тематики на шпальтах «Нашого лемка»- редактор та видавці журналу виразно маркували русинів як вірних Української греко-католицької церкви, чим також хотіли відмежувати власних побратимів від поляків-католиків і православних москвофілів. Поряд із новинами місцевого значення, багато інформації наводилося про буття русинів у різних країнах Західної Європи та за океаном, чим утверджувалася ідея світового зв'язку лемків, об'єднаних ідеєю збереження і плекання батьківських традицій [17; 30]. Аналізуючи матеріали блоку новин, відзначимо важливу критичність у змалюванні проблем життя лемків у міжвоєнній Польщі, наголошення на потребі національної самомобілізації у протистоянні з неприхильними реаліями тогочасного 
суспільно-політичного життя [16]. У зв'язку із цим зі шпальт газети було кинуто оптимістичний клич - «Не ридаймо, а добуваймо!».

Багатьом аспектам русинської проблематики були відведені й інші рубрики газети. Вкажемо на особливу вагомість краєзнавчих та історичних нарисів, присвячених найбільш актуальним аспектам минулого та сучасності лемківського субетносу. Пояснюючи запровадження окремої історичної рубрики, редакція «Нашого лемка» відзначала: «На бажання наших читачів начинаємо 3 цим числом вести історичний куток, щоби дати кожному змогу познакомитися з рідною історією. Людина, яка незнає своєї історії, стає рабом, погноєм чужих» [38]. Історико-краєзнавчі нариси, створені авторитетними знавцями проблематики, мали інформувати читача про історію та культуру своєї малої батьківщини, виховуючи в читацькому середовищі, з одного боку, розуміння унікальності своєї субкультури [31], з іншого - єдності історичної долі лемків з усім українським народом [11; 43; 44]. Цим темам були присвячені такі рубрики: «Події з історії України», «3 наших міст і сіл», «3 рідних сіл», «Мандруймо по рідній землі», «Мандруймо по рідних селах», «Пізнаваймо рідні села» та ін. Найбільшою популярністю серед читачів користувалися статті В. Качмарського [25], В. Косара [28], М. Кипариса [26] та ін.

Як уже йшлося, багато уваги автори «Нашого лемка» присвячували потребі виховання у свого читача почуття єдності з українцями інших земель. Ці соборницькі цінності формувалися через публікації найрізноманітніших жанрів. Так, певною традицією на шпальтах «Нашого лемка» стало відзначати роковини таких знакових у національній історії подій, як Листопадовий зрив [14], акт Злуки [3; 37], бій під Крутами [42; 53] та 950-ліття Володимирового хрещення України [46; 54]. Почуття загальнонаціональної єдності покликані були формувати й дописи, присвячені геніям українського слова Тарасові Шевченку $[1 ; 2 ; 4 ; 7 ; 20 ; 49 ; 50 ; 56]$, Івану Франкові [19; 23; 24; 59], Маркіянові Шашкевичу [27] та ін. Відгукувалися автори газети й на болючі втрати для українського життя, як лемківського [6; 29; 47], так і загальнонаціонального [39; 52, 359-360] масштабу.

Багато уваги редакція «Нашого лемка» приділяла проблемі подолання небезпек для галицьких русинів, котрі походили із самого лемківського середовища. Так, червоною ниткою через усі числа газети проходить антиалкогольна тематика. Пиятика на сторінках газети аргументовано була названа головною загрозою, яка руйнує лемківське середовище з самої глибини - від родини [13]. Тому так багато місця видавці присвятили популяризації аргументів діячів тогочасного протиалкогольного руху, об'єднаних у Товариство «Відродження».

Не меншою загрозою редакцією «Нашого лемка» було названо й особливо великий у лемківському середовищі рівень неписемності [9]. Автори газети у різний спосіб переконували свого читача, що XX ст. належить освіченим людям, бо тільки читаючі народи здатні досягти оміряне [57]. Осмислюючи згадану проблему, автори «Нашого лемка» переконували русинів творити в кожній оселі свої маленькі бібліотеки та ділитися літературою з сусідами і земляками [5]. «Хто пізнає раз один вартість доброї книжки, - переконував дописувач «Нашого лемка», - буде ціле своє життя її вірним другом, не відречеться такого великого приятеля, ні в смутку, ні в радости. Тому кожний повинен читати нашу українську книжку. В найдальші закутини нашого рідного краю піде вона сіяти здорове зерно любови до всего, що наше рідне, дороге» [58]. 3 огляду на проблему масової неписемності, зрозумілою стає той пієтет, який автори видання висловлювали до найстаршої української культурної інституції «Просвіти», велично називаючи іiі «Матір'ю» [12; 18]. Доланню масової неписемності була відведена спеціальна рубрика «Освітньо-виховна сторінка».

Життєвості лемківського світу загрожувала також неконтрольована еміграція лемків за океан, котра призводила до вилюднення регіонів постійного заселення. Один із авторів газети із сумом відзначав: «Ми, лемки, як ті вічні скитальці жиди. Щоби лише десь якийсь шахрай агент збирав підписи на якусь еміграцію, ми вже готові» [33]. Внаслідок такої масової еміграції, місця історичного перебування займали колоністи, переважно польські, котрі знищували пам'ятки русинської архітектури, руйнуючи віковічний культурний ландшафт. Також і на нових місцях перебування, твердили дописувачі газети, лемки не можуть відродити історичних форм буття, поступово втра- 
чаючи власну етнічну самобутність. Тож зі сторінок «Нашого лемка» було кинуто гасло «Не покидайте рідних сіл» [34; 51].

Орієнтація редакторів «Нашого лемка» на найширше коло читачів проглядалася у прискіпливій увазі до літературно-публіцистичної складової часопису, що вражає своєю різноманітністю. Тут бачимо як високі зразки народної обрядової культури (насамперед, колядки та народні пісні), так і літературно-поетичні твори митців-русинів. Найбільш часто друкувалися твори визнаних лемківських майстрів слова Гр. Гануляка, І. Филипчака, Г. Марусина, Т. Перейми, І. Лукавиченка, М. Мартинюка, С. Вархоляка, Р. Антоновича, А. Аверченка, О. Костаревича, М. Проця, М. Ревака та, звісно ж, самого редактора Ю. Тарновича, який під літературними творами часто підписувався псевдонімом Юліан Бескид. Серед публіцистів «Нашого лемка» передовсім згадаємо геніального русина-митця Никофора Дровняка, котрий був одним із дописувачів видання з Криниці [36]. Підвищити читацьку культуру свого читача «Наш лемко» намагався через рубрику «Нові книжки», де повідомлялося про всі значущі новинки українознавчої літератури.

Допомогою в щоденному житті кожного лемка слугували матеріали рубрики «Господарська сторінка», котра нерідко займала дві газетні шпальти. Під цією рубрикою друкувалися найрізноманітніші корисні господарські поради, практичні підказки раціонального ведення родинних фінансів, заходи 3 убезпечення себе перед фінансовим шахрайством (доволі поширеним тогочасним явищам) тощо. Особливо багато на економічні теми писав Володимир Кліш, а цикл його статей «Творім сильні основи» виявився настільки популярним, що вийшов окремим виданням у серії «Бібліотека Лемківщини». «Господарська сторінка» була чи не найбільш популярною у читацькому середовищі, про що свідчили численні листи від шанувальників «Нашого лемка» із запитаннями, відповіді на які й формували змістову наповненість газети. Своєрідним супутником згаданої рубрики була колонка «Наші реферати», що містила важливі поради для самоорганізації громадського життя.

Ознакою певних емансипаційних тенденцій у традиційному русинському середовищі стало запровадження для читачок «Нашого лемка» окремої рубрики - «Жіноча сторінка». Матеріали цієї тематичної частини газети розкривали своїм читачкам розмаїття лемківських господарських секретів, популяризували новітні педагогічні практики, пропагували традиції русинської культури. Все це, як твердили дописувачі «Нашого лемка», повинно сприяти виробленню більш активної громадської позиції жінки-лемкині. Першим кроком до такої зміни пасивної ролі своїх читачок редакція газети вважала нав'язання ними епістолярного діалогу зі своєю газетою [15].

Безвиглядність національного державотворення у міжвоєнний час наприкінці 1930-х рр. змінилася надією на те, що світова криза може принести визволення українському народу. Тому найвизначнішою подією другої половини 1938 - початку 1939 р. була визнана поява на політичній карті Європи незалежної української держави - Карпатської України. Цьому була присвячена навіть окрема рубрика «У Карпатській Україні». «Наш лемко» на цю подію відреагував численними дописами інформаційного характеру, в яких із захопленням йшлося про відродження української державності. Читачів знайомили з чоловими постатями новоствореної держави Августином Волошиним та Михайлом Брящайком, підкреслювався демократичний характер їхньої політики у всіх сферах громадського життя [55].

Утім, згаданим оптимістичним надіям не судилося стати тривалою історичною реальністю. Кінець 1930-х рр. приніс розуміння невідворотності катастрофи, що наближується. У день вибуху Другої світової війни світ побачило останнє число «Нашого лемка». Його автори, ще не знаючи про початок найкривавішої бійні в історії людства, намагалися застерегти своїх читачів від необдуманих кроків, вказати можливі орієнтири в непевному майбутньому: «Важкі часи, які надходять, вимагають від нашого громадянства величезної внутрішньої дисципліни, опанування нервів і спокою. Одним із найважніших завдань хвилини - це підняти в нашому нутрі безоглядну й безпардонну боротьбу із усякими диверсіями та агентурами. Буде досить ворожих сил, які схочуть для своїх цілей послужитися українським аргументом, українськими жертвами й українською кров'ю. Буде досить таких, які схочуть нашими руками собі каштани 3 огню вигортати. Буде досить таких, що - під найбільш патріотичними претекстами - будуть послугуватися найбільш вирафінованими провокаціями, щоб стягати на нас знищуючі репресії й пацифікації. Нічиї слабі 
нерви, нічия ненависть і жадоба відплати, нічиї емоції між українцями не сміють створювати на «власну історичну відповідальність» довершених фактів, які своїми наслідками мусять потім падати на цілу суспільність!» [48].

Висновки. Проведений аналіз дає підставу переконливо ствердити, що «Наш Лемко» посідає особливе місце серед русинської періодики XX ст., оскільки газета була єдиним українським часописом міжвоєнного двадцятиліття не тільки адресованим лемківському читачеві, але й твореним самими лемками. Поряд із реалізацією важливого завдання внутрішньої мобілізації самого русинського середовища, «Наш Лемко» також презентував зовнішньому світу русинів як політично дозрілий субетнос, представники якого, всупереч національному тиску держави-окупанта, артикулюють своє національне самосприйняття у поняттях і термінах українства. Тим самим було утверджено важливу традицію української самоідентичності лемків у час, коли наш народ долав складні внутрішні та зовнішні виклики.

\section{СПИСОК ВИКОРИСТАНИХ ДЖЕРЕЛ І ЛІТЕРАТУРИ}

1. «Учітеся брати мої» // Наш лемко. - 1937. - Ч. 5. - С. 1.

2. 125-ліття народження Тараса Шевченка // Наш лемко. - 1939. - Ч. 6. - С. 1.

3. 22 січня 1918 року // Наш лемко. - 1938. - Ч. 3. - С. 3.

4. А. Г-ко. Західна Лемківщина віддала Т. Шевченкові // Наш лемко. - 1934. - Ч. 10. - С. 1.

5. Березівський К. Чому кожна наша хата має бути читальнею? / К. Березівський // Наш лемко. 1938. - Ч. 3. - С. 2-3.

6. Болюча втрата (Василь Левчик) // Наш лемко. - 1938. - Ч. 6. - С. 9.

7. В 75-літню річницю смерти нашого найбільшого Генія України - Тараса Шевченка // Наш Лемко. Львів, 1936. - Ч. 6. - С. 5.

8. Вавричин М. Юліан Тарнович - редактор газети «Наш лемко» / Марія Вавричин // Відтворення України: історія картографії, краєзнавство, біографістика / Упоряд. Н. Паславська, Н. Халак. - Львів: ІУАД ім. М. С. Грушевського, 2012. - С. 441-446.

9. Виповіджмо війну темноті і баламуті! «Наш Лемко» в кожній лемківській хаті!! Іван Франко // Наш лемко. - 1934. - Ч. 13. - С. 2.

10. Всеволод Ярославич. Москвофільство на Лемківщині / Всеволод Ярославич // Наш лемко. - 1939. Ч. 10. - С. 7 .

11. Всеволод Ярославич. Християнство на Лемківщині (Від найдавніших часів до церковної, Берестейської унії) / Всеволод Ярославич // Наш лемко. - 1939. - Ч. 1. - С. 11.

12. Всенародний мовчазний поклін Матері «Просвіті» // Наш лемко. - 1938. - Ч. 11. - С. 1.

13. Геть отрую з наших хат // Наш Лемко. - Львів, 1935. - Ч. 5. - С. 3.

14. День 1 листопада для нашого народу // Наш лемко. - 1934. - Ч. 21. - С. 3.

15. Дівчата и невістки, дале, так не може бити // Наш лемко. - 1934. - Ч. 9. - С. 3.

16. Для добра Нації - всі в її ряди! Чому не було на Лемківщині єдности // Наш лемко. - 1935. - Ч. 5. C. 2 .

17. Другий Зїзд організації О.Л.З.У.3. // Наш лемко. - 1938. - Ч. 1. - С. 5.

18. За вірність прапорові Просвіти! // Наш лемко. - 1938. - Ч. 13. - С. 3.

19. За культуру українського народу (У двадцяту річницю смерти Івана Франка) // Наш Лемко. - Львів, 1936. - Ч. 11. - С. 2.

20. І оживе добра слава, Слава України // Наш Лемко. - Львів, 1935. - Ч. 6. - С. 4.

21. . Ш. Даремні зусилля // Наш лемко. - 1938. - Ч. 1. - С. 3.

22. І І. Ш. Вовки в овечій шкурі // Наш лемко. - 1938. - Ч. 2. - С. 3.

23. Іван Франко // Наш лемко. - 1934. - Ч. 11. - С. 3.

24. Іван Франко // Наш лемко. - 1939. - Ч. 10. - С. 3.

25. Качмарський В. Над долішнім Вислоком / В. Качмарський // Наш лемко. - 1939. - Ч. 9. - С. 8.

26. Кипарис М. 3 історії наших сіл / М. Кипарис // Наш лемко. - 1939. - Ч. 16. - С. 11-12.

27. Концерт в честь М. Шашкевича в Коросні // Наш лемко. - 1934. - Ч. 17. - С.7.

28. Косар А. На межі двох повітів / А. Косар // Наш лемко. - 1939. - Ч. 16. - С. 10.

29. Косить смерть (о. Малиняк Адріян помер) // Наш лемко. - 1938. - Ч. 7. - С. 3.

30. Лемки за морем // Наш лемко. - 1938. - Ч. 10. - С. 5.

31. Лемківщина в народних переказах // Наш лемко. - 1938. - Ч. 1. - С. 12.

32. Лемківщино рідна, заколишу в красі твоїй / За ред. В. Денисюка, О. Кровицької. - Львів, 2002. $325 \mathrm{c}$. 
33. Не емігруйте до Славонії! // Наш лемко. - 1934. - Ч. 17. - С. 4.

34. Не покидайте рідних сіл // Наш лемко. - 1938. - Ч. 6. - С. 7.

35. Не тішся враже // Наш лемко. - 1939. - Ч. 5. - С. 4.

36. Никофор. Криниця-село / Никофор // Наш лемко. - 1939. - Ч. 12. - С. 11-12.

37. Переломові дні в історії України. 22 січня - Україна понад усе! // Наш лемко. - 1935. - Ч. 3. - С. 2.

38. Події з історії України // Наш лемко. - 1934. - Ч. 16. - С. 5.

39. Помер М. Грушевський // Наш Лемко. - Львів, 1934. - Ч. 24. - С. 4.

40. Про што буде писати «Наш Лемко» // Наш Лемко. - 1934. - № 1. - С. 2.

41. Редакція «Нашого Лемка». До наших Читачів // Наш Лемко. - 1934. - № 1. - С. 2.

42. Роковини бою під Крутами // Наш лемко. - 1938. - Ч. 4. - С. 1.

43. Роман Переяславич. Сяніцькі церкви й парохія в давнині / Роман Переяславич // Наш лемко. 1938. - Ч. 13. - С. 10.

44. Роман Переяславич. Три найсвітліші моменти Сянока / Роман Переяславич // Наш лемко. - 1938. Ч. 15. - C. 11 .

45. Савка М. Тарнович (Бескид) Юліян / М. Савка // Українська журналістика в іменах. Матеріали до енциклопедичного словника / За ред. М. Романюка. - Вип. 6. - Львів, 1999. - С. 327-330.

46. Скоморовський Ю. Ювілейний рік християнської України / Ю. Скоморовський // Наш лемко. 1938. - Ч. 15. - С. 2.

47. Смерть свідомого кооператора (Василь Полянський) // Наш лемко. - 1938. - Ч. 20. - С. 8.

48. Становище українства в обличчі війни. Збережемо нашу національну гідність // Наш лемко. 1939. - Ч. 17. - C. 1.

49. Східна Лемківщина віддала поклін Шевченкові // Наш лемко. - 1934. - Ч. 9. - С. 2.

50. Тарас Григорович Шевченко. В 120-ту річницю уродин // Наш лемко. - 1934. - Ч. 5. - С. 1.

51. Тарнович Ю. Перелетні птиці. Під розвагу сезоновим робітникам / Юліан Тарнович // Наш лемко. 1939. - Ч. 15. - C. 2.

52. Тельвак В. Творча спадщина Михайла Грушевського в оцінках сучасників (кінець XIX - 30-ті роки ХХ століття) / Віталій Тельвак. - Київ-Дрогобич: «Вимір», 2008. - 494 с.

53. Триста хоробрих. Хто і за що боровся під Крутами // Наш лемко. - 1935. - Ч. 4. - С. 2.

54. У 950-ліття Володимирового хрещення України // Наш лемко. - 1938. - Ч. 8. - С. 2.

55. У Карпатській Україні // Наш лемко. - 1939. - Ч. 1. - С. 6-7.

56. Улаштовуйте Шевченківський Концерт // Наш лемко. - 1938. - Ч. 6. - С. 1.

57. Через освіту до кращого завтра // Наш лемко. - 1938. - Ч. 4. - С. 7.

58. Чому треба читати книжку? // Наш лемко. - 1934. - Ч. 3. - С. 2.

59. Як жив і працював Іван Франко // Наш лемко. - 1937. - Ч. 12. - С. 3.

\section{REFERENCES}

1. «Uchitesia braty moi» // Nash lemko. - 1937. - Ch. 5. - S. 1.

2. 125-littia narodzhennia Tarasa Shevchenka // Nash lemko. - 1939. - Ch. 6. - S. 1.

3. 22 sichnia 1918 roku // Nash lemko. -1938 . - Ch. 3. - S. 3.

4. A. H-ko. Zakhidna Lemkivshchyna viddala T. Shevchenkovi // Nash lemko. - 1934. - Ch. 10. - S. 1.

5. Berezivskyi K. Chomu kozhna nasha khata maie buty chytalneiu? / K. Berezivskyi // Nash lemko. 1938. - Ch. 3. - S. 2-3.

6. Boliucha vtrata (Vasyl Levchyk) // Nash lemko. - 1938. - Ch. 6. - S. 9.

7. V 75-litniu richnytsiu smerty nashoho naibilshoho Heniia Ukrainy - Tarasa Shevchenka // Nash Lemko.Lviv, 1936. - Ch. 6. - S. 5.

8. Vavrychyn M. Yulian Tarnovych - redaktor hazety «Nash lemko»/ Mariia Vavrychyn // Vidtvorennia Ukrainy: istoriia kartohrafii, kraieznavstvo, biohrafistyka / Uporiad. N. Paslavska, N. Khalak. - Lviv: IUAD im. M. S. Hrushevskoho, 2012. - S. 441-446.

9. Vypovidzhmo viinu temnoti i balamuti! «Nash Lemko» v kozhnii lemkivskii khati!! Ivan Franko // Nash lemko. - 1934. - Ch. 13. - S. 2.

10. Vsevolod Yaroslavych. Moskvofilstvo na Lemkivshchyni / Vsevolod Yaroslavych // Nash lemko. 1939. - Ch. 10. - S. 7.

11. Vsevolod Yaroslavych. Khrystyianstvo na Lemkivshchyni (Vid naidavnishykh chasiv do tserkovnoi, Beresteiskoi unii) / Vsevolod Yaroslavych // Nash lemko. - 1939. - Ch. 1. - S. 11.

12. Vsenarodnyi movchaznyi poklin Materi «Prosviti» // Nash lemko. - 1938. - Ch. 11. - S. 1.

13. Het otruiu z nashykh khat // Nash Lemko. - Lviv, 1935. - Ch. 5. - S. 3.

14. Den 1 lystopada dlia nashoho narodu // Nash lemko. - 1934. - Ch. 21. - S. 3. 
15. Divchata y nevistky, dale, tak ne mozhe byty // Nash lemko. - 1934. - Ch. 9. - S. 3.

16. Dlia dobra Natsii - vsi v yii riady! Chomu ne bulo na Lemkivshchyni yednosty // Nash lemko. - 1935. Ch. 5. - S. 2.

17. Druhyi Zizd orhanizatsii O.L.Z.U.Z. // Nash lemko. - 1938. - Ch. 1. - S. 5.

18. Za virnist praporovi Prosvity! // Nash lemko. - 1938. - Ch. 13. - S. 3.

19. Za kulturu ukrainskoho narodu (U dvadtsiatu richnytsiu smerty Ivana Franka) // Nash Lemko. - Lviv, 1936. - Ch. 11. - S. 2.

20. I ozhyve dobra slava, Slava Ukrainy // Nash Lemko. - Lviv, 1935. - Ch. 6. - S. 4.

21. I. Sh. Daremni zusyllia // Nash lemko. - 1938. - Ch. 1. - S. 3.

22. I. Sh. Vovky v ovechii shkuri // Nash lemko. -1938 . - Ch. 2. - S. 3.

23. Ivan Franko // Nash lemko. - 1934. - Ch. 11. - S. 3.

24. Ivan Franko // Nash lemko. - 1939. - Ch. 10. - S. 3.

25. Kachmarskyi V. Nad dolishnim Vyslokom / V. Kachmarskyi // Nash lemko. - 1939. - Ch. 9. - S. 8.

26. Kyparys M. Z istorii nashykh sil / M. Kyparys // Nash lemko. - 1939. - Ch. 16. - S. 11-12.

27. Kontsert v chest M. Shashkevycha v Korosni // Nash lemko. -1934 . - Ch. 17. - S.7.

28. Kosar A. Na mezhi dvokh povitiv / A. Kosar // Nash lemko. - 1939. - Ch. 16. - S. 10.

29. Kosyt smert (o. Malyniak Adriian pomer) // Nash lemko. - 1938. - Ch. 7. - S. 3.

30. Lemky za morem // Nash lemko. - 1938. - Ch. 10. - S. 5.

31. Lemkivshchyna v narodnykh perekazakh // Nash lemko. - 1938. - Ch. 1. - S. 12.

32. Lemkivshchyno ridna, zakolyshu v krasi tvoii / Za red. V. Denysiuka, O. Krovytskoi. - Lviv, 2002. $325 \mathrm{~s}$.

33. Ne emihruite do Slavonii! // Nash lemko. - 1934. - Ch. 17. - S. 4.

34. Ne pokydaite ridnykh sil // Nash lemko. -1938 . - Ch. 6. - S. 7.

35. Ne tishsia vrazhe // Nash lemko. - 1939. - Ch. 5. - S. 4.

36. Nykofor. Krynytsia-selo / Nykofor // Nash lemko. - 1939. - Ch. 12. - S. 11-12.

37. Perelomovi dni v istorii Ukrainy. 22 sichnia - Ukraina ponad use! // Nash lemko. - 1935. - Ch. 3. - S. 2.

38. Podii z istorii Ukrainy // Nash lemko. -1934 . - Ch. 16. - S. 5.

39. Pomer M. Hrushevskyi // Nash Lemko. - Lviv, 1934. - Ch. 24. - S. 4.

40. Pro shto bude pysaty «Nash Lemko» // Nash Lemko. - 1934. - № 1. - S. 2.

41. Redaktsiia «Nashoho Lemka». Do nashykh Chytachiv // Nash Lemko. - 1934. - № 1. - S. 2.

42. Rokovyny boiu pid Krutamy // Nash lemko. - 1938. - Ch. 4. - S. 1.

43. Roman Pereiaslavych. Sianitski tserkvy y parokhiia v davnyni / Roman Pereiaslavych // Nash lemko. 1938. - Ch. 13. - S. 10.

44. Roman Pereiaslavych. Try naisvitlishi momenty Sianoka / Roman Pereiaslavych // Nash lemko. - 1938. Ch. 15. - S. 11 .

45. Savka M. Tarnovych (Beskyd) Yuliian / M. Savka // Ukrainska zhurnalistyka v imenakh. Materialy do entsyklopedychnoho slovnyka / Za red. M. Romaniuka. - Vyp. 6. - Lviv, 1999. - S. 327-330.

46. Skomorovskyi Yu. Yuvileinyi rik khrystyianskoi Ukrainy / Yu. Skomorovskyi // Nash lemko. - 1938. Ch. 15. - S. 2.

47. Smert svidomoho kooperatora (Vasyl Polianskyi) // Nash lemko. - 1938. - Ch. 20. - S. 8.

48. Stanovyshche ukrainstva $\mathrm{v}$ oblychchi viiny. Zberezhemo nashu natsionalnu hidnist // Nash lemko. 1939. - Ch. 17. - S. 1.

49. Skhidna Lemkivshchyna viddala poklin Shevchenkovi // Nash lemko. - 1934. - Ch. 9. - S. 2.

50. Taras Hryhorovych Shevchenko. V 120-tu richnytsiu urodyn // Nash lemko. - 1934. - Ch. 5. - S. 1.

51. Tarnovych Yu. Pereletni ptytsi. Pid rozvahu sezonovym robitnykam / Yulian Tarnovych // Nash lemko. 1939. - Ch. 15. - S. 2.

52. Telvak V. Tvorcha spadshchyna Mykhaila Hrushevskoho v otsinkakh suchasnykiv (kinets XIX - 30-ti roky XX stolittia) / Vitalii Telvak. - Kyiv-Drohobych: «Vymir», 2008. - 494 s.

53. Trysta khorobrykh. Khto i za shcho borovsia pid Krutamy // Nash lemko. - 1935. - Ch. 4. - S. 2.

54. U 950-littia Volodymyrovoho khreshchennia Ukrainy // Nash lemko. - 1938. - Ch. 8. - S. 2.

55. U Karpatskii Ukraini // Nash lemko. - 1939. - Ch. 1. - S. 6-7.

56. Ulashtovuite Shevchenkivskyi Kontsert // Nash lemko. - 1938. - Ch. 6. - S. 1.

57. Cherez osvitu do krashchoho zavtra // Nash lemko. - 1938. - Ch. 4. - S. 7.

58. Chomu treba chytaty knyzhku? // Nash lemko. - 1934. - Ch. 3. - S. 2.

59. Iak zhyv i pratsiuvav Ivan Franko // Nash lemko. - 1937. - Ch. 12. - S. 3.

Стаття надійшла до редакиії 20.10.2017 p. 